
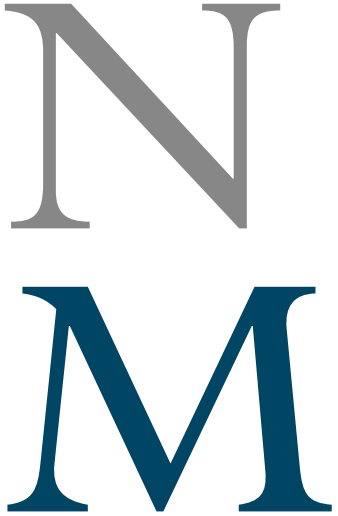
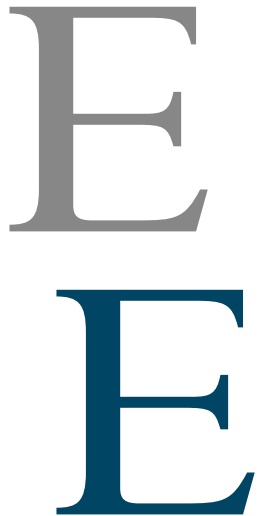
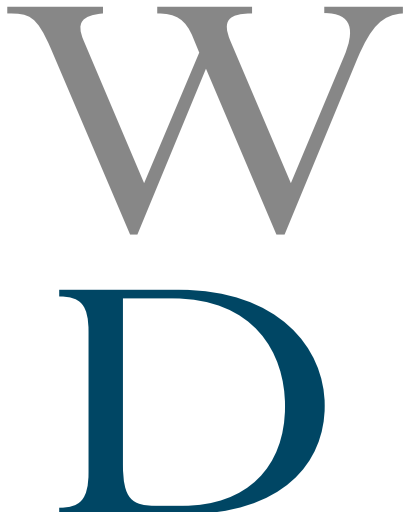
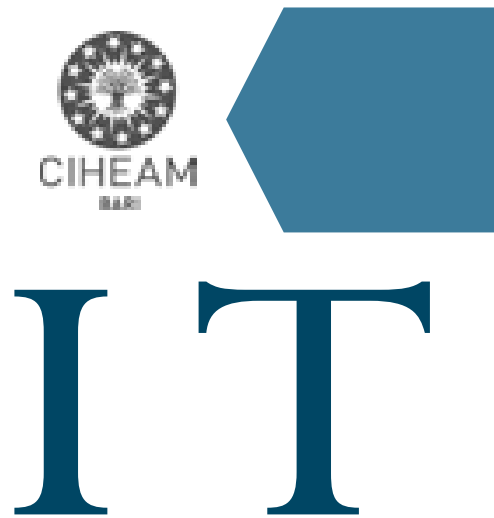

MEDITERRANEAN JOURNAL OF ECONOMICS, AGRICULTURE AND ENVIRONMENT

Poste Italiane Spa Spedizione in Abbonamento Postale Periodico ROC Centro Nord aut. $\mathrm{N}^{\circ} 0029-€ 15,00$.

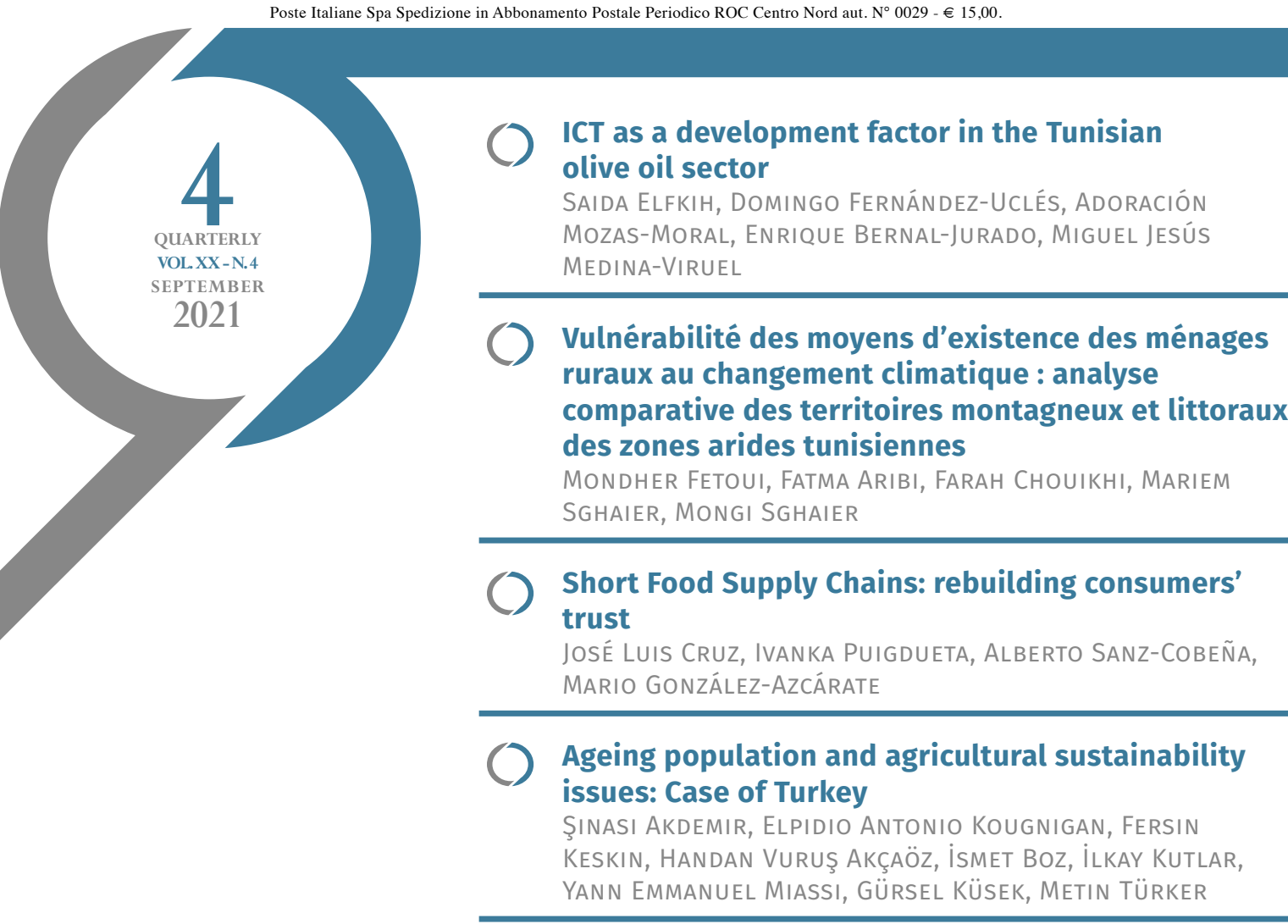




\title{
The factors affecting the marketing channel selection in sheep farming: A Turkish case study
}

\author{
Ferhan Kaygi̇si̇z*, Fìli̇z AKdaĞ**
}

DOI: $10.30682 / \mathrm{nm} 2104 \mathrm{f}$

JEL codes: Q12, Q13

\begin{abstract}
This study was conducted to determine sheep farmers'selection of marketing channels in livestock sales and the factors affecting their choices. The research data were generated from the survey data of 53 enterprises selected via simple random sampling method in Samsun province in 2019. In this research, descriptive statistics were used to determine some characteristics of the sheep farmers, and the chi-square test was employed to compare the farmers' characteristics according to the selection of the marketing channels. According to the results of the study, four marketing channels were identified to be efficient in livestock marketing. These were final consumers, brokers, retailers, and mixed channels. Besides, it was determined that the variables of selling additional products (milk, cheese, fleece) in the enterprise other than livestock, being a member of the Sheep and Goat Breeders Association, and the reason of choosing marketing channels had an impact $(P<0.05)$ on the selection of marketing channels.
\end{abstract}

Keywords: Livestock marketing, Marketing channels, Sheep farmers.

\section{Introduction}

Sheep breeding has an important place among animal production activities. This is because grasslands and pastures that are not used for other purposes can be utilized through sheep breeding, and main products are obtained, such as meat, milk, fleece, leather, and fertilizer. Besides, as a conventional practice from time immemorial, it is a production branch in which certain infrastructure and experience have been gained in terms of know-how and stock farming. Since sheep breeding is based on pasture, feed costs are low, the transition-to-yield period of animals is short, adaptation and breeding abilities are high, capital and fixed investment expens- es are low, and the foreign-source dependency for breeding animals is relatively less (Tamer, 2014). According to the data by the Turkish Statistical Institute for the year 2019, there is a total of 38.449 million sheep in Turkey (TURKSTAT, 2019). The amount of meat obtained from sheep is 100.83 tons, and this amount constitutes $9 \%$ of the total meat production. Rural animal breeders are generally smallscale enterprises with poor bargaining power. Therefore, animal products' price in rural areas forms in oligopsony market conditions (Cevger et al., 2011). In Turkey, the existing animal and animal products marketing system has a structure where levels other than breeders (especially a large number of interme-

\footnotetext{
* Istanbul University-Cerrahpasa, İstanbul, Turkey.

** Department of Animal Breeding, Faculty of Veterinary Medicine, Ondokuz Mayıs University, Samsun, Turkey. Corresponding author: ferhan_64@yahoo.com
} 
diaries) earn higher incomes. This structure is the most significant reason for the imbalance between producer and consumer prices. The distortion and price instability in the marketing system are at a high level. Lack of organization in sheep breeding causes the breeders to have insufficient bargaining power in the supply of inputs and make them unable to sell their products for their worth. Since the sheep breeders need money, they usually sell their products at low prices to the village collectors, drovers, or brokers that come to buy their animals, and they have to procure the inputs for the next production period at high prices (Kaymak, 2015). There is a shortage of roughage due to the insufficient feeding capacity of the grasslands and the limited production of forage crops. Shepherd's wage is a significant cost among other inputs in sheep and goat farming. On the other hand, it has become difficult to find qualified shepherds as the young population migrated from the region as a result of their inability to earn a living (Aksoy and Yavuz, 2012). Livestock farming input costs are considerably high in Turkey. In addition to increasing input costs, decreasing producer share in consumer prices for many products in the marketing chain consisting of the producer - collector - breeder - merchant - processor - wholesaler - retailer and consumer reveals that the support provided to production actually flows to the processes after production. In the ovine breeding sector, the organization of farmers has a weak structure. Breeder organizations in Turkey are formed as cooperatives, breeder associations, and producer unions, and their share in the marketing and processing of products besides their bargaining power are very low. Therefore, they have no effect on price formation (Ministry of Development, 2014). The main purpose of the Sheep and Goat Breeders Associations is to implement all kinds of breeding programs in order to raise high-yield animals. Besides, although the associations are also assigned duties in marketing and production issues, their marketing activities are very limited. In their study, Seçer and Boğa (2016) reported that $89.7 \%$ of the producers stated that big buyers, $7.7 \%$ big traders, and $2.6 \%$ cooperatives were effective in determining prices in animal product sales. The producers stated the most important problems they faced in the marketing of animal products as the low number of buyers, low purchase prices, insufficiency of extension and support, lack of cash, lack of market information, and high loan interest rates (Seçer and Boğa, 2016; Tamer, 2014).

Within the scope of marketing agricultural products in Turkey, it is observed that various electronic sales platforms have been built, both from producer to consumer (B2C) and from producer to commercial enterprises (B2B). However, in marketing agricultural products, the opportunities of e-commerce cannot be utilized adequately. Furthermore, depending on the increase in demand for local food and for market structures providing them in our country, there are food center-type structures in different models, albeit insufficient. The most important examples of this are cooperatives, producer markets, organic markets, and food banks (Albayrak et al., 2020).

The marketing activities in the agricultural sector are not much advanced compared to other sectors. Since the level of organization in this sector is low and their opportunities to add value to the product are very little, the marketing orientations of most breeders are limited to the activity of selling their products (Haines, 1999).

In general, there is limited knowledge about the factors affecting the marketing channel choices of livestock breeders and the marketing strategies they employ. In the studies that investigated the livestock marketing in Turkey, mainly marketing margins (Aral et al., 2016) and market power and price asymmetry (Ozer, 2011; Bölük and Karaman, 2017) were discussed. In the study conducted by Aral et al. (2016) it was reported that $40,83 \%$ of the price paid by the consumer for lamb meat goes to intermediaries. Ozer's (2011) study put forward that producer prices were insensitive to price incentives, and the decisions of policymakers to intervene in production by using price incentives would not be reflected in the producers. There was only one study found, which was aimed at determining the factors that affect the marketing channel selections of sheep breeders. In the study conducted by Kadanali et al. (2015) in the province of Ağrı, the factors affecting the marketing channel selections of sheep breeders were defined as 
farmer's knowledge and herd size, trust in intermediaries and price, sales and relationships, and physical conditions of other farmers.

There are some studies discussing the marketing strategies applied by the breeders in several livestock businesses in the world (Davies, 2001; Tsourgiannis et al., 2005; Tsourgiannis et al., 2008); studies revealing the factors that have a significant influence on the marketing decisions of the enterprises (Tsourgiannis et al., 2005; Tsourgiannis et al., 2008; Mutura et al., 2015; De Bruyn et al., 2001; Gong et al., 2007; Srinivas et al., 2014; Benedek et al., 2014; Nyaupane and Gillespie, 2011) and investigating marketing channel structures and applied strategies in different sectors (Escobar and Gil, 2016; Fetoui et al., 2020).

In Turkey, there is a lack of knowledge concerning existing marketing practices in terms of the development of the sheep breeding industry. This study aims to determine the channels used by sheep breeders to sell their animals and the factors that affect their selection of these channels. The present study will be helpful in order to increase the economic sustainability and competitiveness of sheep breeding enterprises.

\section{Materials and methods}

The research material consisted of breeders' personal information and general data on production activities, marketing activities, and factors affecting the marketing channel preferences in a total of 70 sheep farming enterprises located in Tekkeköy, Bafra, Vezirköprü, and Ladik districts in Samsun province, the region with intense sheep breeding activities. The data were obtained from face-to-face surveys with business owners. The questionnaire was prepared by utilizing the studies of Tsourgiannis et al. (2008), Kadanalı et al. (2015), Davies (2001), and Nyaupane and Gillespie (2011).

In order to determine the number of enterprises to be selected for the research, the total number of sheep farms in the province (3490) and the districts where the enterprises were concentrated were determined by using the report on Business/Small Ruminant numbers prepared by Samsun Directorate of Provincial
Agriculture and Forestry. In line with the data obtained from the records, the number of enterprises between 25-500 heads where sheep businesses were concentrated in the province (2513 enterprises) and Tekkeköy, Bafra, Vezirköprü, and Ladik districts that made up the majority of these enterprises, were determined and included in the research. In the districts included in the scope of the research, a total of 70 enterprises were determined in a way to compose $5 \%$ of a total of 1408 enterprises which had a sheep number between 25-500, these enterprises were randomly selected, and face-to-face surveys were conducted with the business owners (Tsourgiannis et al., 2008). When entering the data of 70 enterprises surveyed for the analysis, the enterprises with missing data were excluded from the assessment, and the data of 53 enterprises in total were used in the analysis.

In the study, descriptive statistics were used to determine the mean values and standard deviations along with frequency and rates pertaining to some characteristics of sheep breeders. The chi-square goodness-of-fit test was applied to compare the factors affecting the choice of marketing channels, and Cochran-MantelHaenszel Statistics were utilized for the within-group comparison of the important features (McDonald, 2014).

\section{Results}

Some characteristics of sheep breeders are given in Table 1 and Table 2.

In this study, it was found that sheep breeders were, on average, 46 years old and had 22 years of experience in sheep breeding (Table 1). In addition, it was determined that owners of sheep breeding businesses were generally male, and they were mostly primary school graduates $(49.1 \%)$. When the findings regarding the incomes of the breeders were examined, it was determined that $39.6 \%$ of them earned income only from sheep breeding, and, in this income, the rate of those selling only live animals (71.7\%) was considerably high. Within income level segments, it was observed that the breeders with an income of over 40000 TL (32.7\%) were more than the others. 
Table 1 - Mean values and standard deviations pertaining to some characteristics of sheep breeders.

\begin{tabular}{|c|c|c|}
\hline Characteristics & Mean & $S D$ \\
\hline The average age of breeders (years) & 46.0 & 11.4 \\
\hline Duration of experience of breeders (years) & 22.0 & 13.6 \\
\hline The share of sheep breeding in total income (\%) & 62.5 & 28.4 \\
\hline Number of sheep (head) & 131.3 & 88.3 \\
\hline Share of livestock sales in the income from sheep breeding (\%) & 92.5 & 17.8 \\
\hline Livestock unit sales price (TL) & 40.7 & 5.4 \\
\hline
\end{tabular}

It was found that a large part of the breeders who participated in the survey had memberships in the sheep and goat breeders' association, whereas the rate of cooperative membership was quite low (18.9\%). It was determined that sheep breeders chose marketing channels for their products mainly based on cash payment, familiarity, and necessity factors, and in product sales, the rate of price-setting by the buyer and the seller together $(45.3 \%)$ was higher than the others (Table 2).

The marketing channels chosen by the sheep breeders and the selection rates of these channels are given in Figure 1. According to the surveys, it was determined that the breeders were marketing their products by choosing direct (final) consumers, brokers, retailers, or multiple channels at once (mixed or hybrid). Among these channels, it was observed that the rate of those choosing brokers was higher than the others.

Figure 1 - Distribution rates of the marketing channel selections.

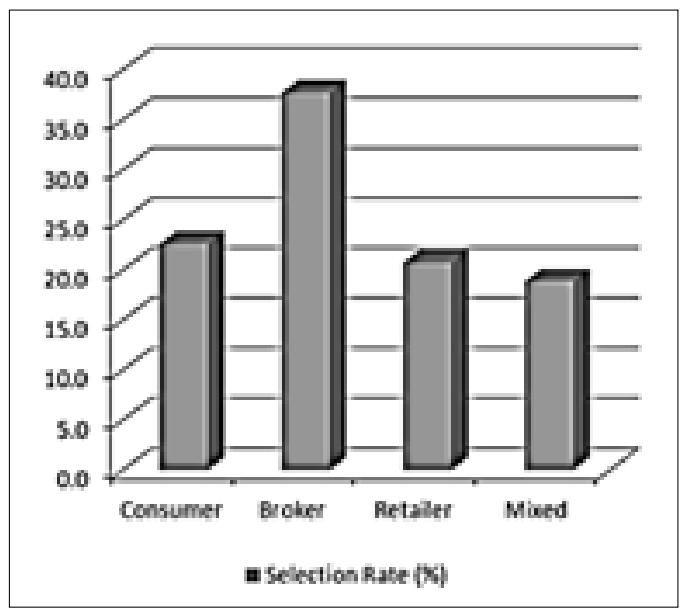

A comparison of sheep breeders' characteristics according to the selection of marketing channels is presented in Table 3. Channels that were not preferred in each of these features were not included in the analysis. The differences between the distribution of the rates of non-livestock product sales, association membership, and reasons for marketing channel selection, according to marketing channels, were determined to be statistically significant $(\mathrm{P}<0.05)$. On the other hand, the differences between the groups in other characteristics according to marketing channels were determined to be insignificant $(\mathrm{P}>0.05)$. Of these characteristics, when the distributions of those selling and those not selling products other than livestock were analyzed by marketing channels: it was determinedthat those selling products other than livestock chose brokers and final consumers more, whereas those selling only livestock chose brokers at a higher rate $(\mathrm{P}<0.05)$. When all breeders were evaluated in terms of association membership, it was determined that among the breeders who were members or not, the rate of those who preferred brokers was higher $(26.42 \%)$ than the others. Also, when association members and non-members were compared within themselves, the rates of those who preferred brokers were found to be higher $(\mathrm{P}<0.05)$ in both groups. When the rates of the reasons for selection were compared in terms of the final consumers, brokers, retailers, and mixed sales channels, it was determined that the highest values were those who chose brokers due to necessity with a rate of $15.09 \%$ and those who chose the mixed marketing channels due to cash payment $(\mathrm{P}<0.01)$ (Table 3$)$. 
Table 2 - Frequency and rates pertaining to some characteristics of sheep breeders (\%).

\begin{tabular}{|c|c|c|}
\hline Characteristics & Frequency & Rate \\
\hline \multicolumn{3}{|l|}{ Gender } \\
\hline Male & 51 & 96.2 \\
\hline Female & 2 & 3.8 \\
\hline \multicolumn{3}{|l|}{ Educational level of breeders } \\
\hline Literate & 2 & 3.8 \\
\hline Primary School & 26 & 49.1 \\
\hline Middle School & 10 & 18.9 \\
\hline High School & 7 & 13.2 \\
\hline University & 7 & 13.2 \\
\hline Illiterate & 1 & 1.9 \\
\hline \multicolumn{3}{|c|}{ Breeders'income-generating activities other than sheep breeding } \\
\hline Yes & 32 & 60.4 \\
\hline No & 21 & 39.6 \\
\hline \multicolumn{3}{|l|}{ Total income level } \\
\hline Less than $20000 \mathrm{TL}$ & 11 & 21.2 \\
\hline $20000-30000 \mathrm{TL}$ & 13 & 25.0 \\
\hline $30000-40000 \mathrm{TL}$ & 12 & 22.1 \\
\hline More than $40000 \mathrm{TL}$ & 17 & 32.7 \\
\hline \multicolumn{3}{|c|}{ Products other than livestock sales in sheep breeding } \\
\hline Yes & 15 & 28.3 \\
\hline No & 38 & 71.7 \\
\hline \multicolumn{3}{|l|}{ Cooperative membership } \\
\hline Yes & 10 & 18.9 \\
\hline No & 43 & 81.1 \\
\hline \multicolumn{3}{|l|}{ Association membership } \\
\hline Yes & 46 & 86.8 \\
\hline No & 7 & 13.2 \\
\hline \multicolumn{3}{|l|}{ Mode of payment of the product price } \\
\hline Cash & 31 & 58.5 \\
\hline Installment & 22 & 41.5 \\
\hline \multicolumn{3}{|c|}{ The reason for choosing the marketing channel } \\
\hline Cash payment & 22 & 41.5 \\
\hline Necessity & 13 & 24.5 \\
\hline Higher price & 2 & 3.8 \\
\hline Familiarity & 13 & 24.5 \\
\hline Proximity & 1 & 1.9 \\
\hline Suitability to the quality of the product & 2 & 3.8 \\
\hline \multicolumn{3}{|c|}{ The person who determines the sale price of the product } \\
\hline Buyer & 11 & 20.8 \\
\hline Seller & 10 & 18.9 \\
\hline Both of them & 24 & 45.3 \\
\hline Other & 8 & 15.1 \\
\hline \multicolumn{3}{|c|}{ The place for learning market knowledge regarding product prices } \\
\hline By visiting the market directly & 27 & 50.9 \\
\hline From other breeders & 15 & 28.3 \\
\hline From friends & 6 & 11.3 \\
\hline From the Internet & 2 & 3.8 \\
\hline Other & 3 & 5.7 \\
\hline
\end{tabular}


Table 3 - Factors affecting the marketing channel selection.

\begin{tabular}{|c|c|c|c|c|c|c|c|c|c|}
\hline \multirow[t]{2}{*}{ Characteristics } & \multicolumn{2}{|c|}{$\begin{array}{c}\text { Final } \\
\text { Consumer }\end{array}$} & \multicolumn{2}{|c|}{ Broker } & \multicolumn{2}{|c|}{ Retailer } & \multicolumn{2}{|c|}{ Mixed } & \multirow[t]{2}{*}{$\begin{array}{c}P \\
\text { value } \\
\end{array}$} \\
\hline & $N$ & $\%$ & $N$ & $\%$ & $N$ & $\%$ & $N$ & $\%$ & \\
\hline \multicolumn{10}{|l|}{ Gender } \\
\hline Male & 12 & 22.64 & 18 & 33.96 & 11 & 20.75 & 10 & 18.87 & \multirow{2}{*}{0.258} \\
\hline Female & 0 & 0.00 & 2 & 3.77 & 0 & 0.00 & 0 & 0.00 & \\
\hline \multicolumn{10}{|l|}{ Educational level of breeders } \\
\hline Literate & 0 & 0.00 & 2 & 3.77 & 0 & 0.00 & 0 & 0.00 & \multirow{6}{*}{0.428} \\
\hline Primary School & 7 & 13.21 & 12 & 22.64 & 3 & 5.66 & 4 & 7.55 & \\
\hline Middle School & 2 & 3.77 & 2 & 3.77 & 3 & 5.66 & 3 & 5.66 & \\
\hline High School & 1 & 1.89 & 1 & 1.89 & 4 & 7.55 & 1 & 1.89 & \\
\hline University & 2 & 3.77 & 2 & 3.77 & 1 & 1.89 & 2 & 3.77 & \\
\hline Illiterate & 0 & 0.00 & 1 & 1.89 & 0 & 0.00 & 0 & 0.00 & \\
\hline \multicolumn{10}{|c|}{ Breeders' income-generating activities other than sheep breedin } \\
\hline Yes & 4 & 7.55 & 14 & 26.42 & 9 & 16.98 & 5 & 9.43 & \multirow{2}{*}{0.066} \\
\hline No & 8 & 15.09 & 6 & 11.32 & 2 & 3.77 & 5 & 9.43 & \\
\hline \multicolumn{10}{|l|}{ Total income level } \\
\hline Less than $20000 \mathrm{TL}$ & 2 & 3.77 & 4 & 7.55 & 5 & 9.43 & 0 & 0.00 & \multirow{4}{*}{0.169} \\
\hline $20000-30000 \mathrm{TL}$ & 2 & 3.77 & 5 & 9.43 & 1 & 1.89 & 5 & 9.43 & \\
\hline $30000-40000 \mathrm{TL}$ & 4 & 7.55 & 3 & 5.66 & 2 & 3.77 & 3 & 5.66 & \\
\hline More than $40000 \mathrm{TL}$ & 4 & 7.55 & 8 & 15.06 & 3 & 5.66 & 2 & 3.77 & \\
\hline \multicolumn{10}{|c|}{ Products other than livestock sales in sheep breeding } \\
\hline Yes & 5 & 9.43 & 7 & 13.21 & 0 & 0.00 & 3 & 5.66 & \multirow{2}{*}{$0.030^{* *}$} \\
\hline No & 7 & 13.21 & 13 & 24.53 & 11 & 20.75 & 7 & 13.21 & \\
\hline \multicolumn{10}{|l|}{ Cooperative membership } \\
\hline Yes & 3 & 5.66 & 2 & 3.77 & 3 & 5.66 & 2 & 3.77 & \multirow{2}{*}{0.585} \\
\hline No & 9 & 19.98 & 18 & 33.96 & 8 & 15.09 & 8 & 15.09 & \\
\hline \multicolumn{10}{|l|}{ Association membership } \\
\hline Yes & 12 & 22.64 & 14 & 26.42 & 11 & 20.75 & 9 & 16.98 & \\
\hline No & 0 & 0.00 & 6 & 11.32 & 0 & 0.00 & 1 & 1.89 & 0.015 \\
\hline Mode of payment of the product price & & & & & & & & & \\
\hline Cash & 7 & 13.21 & 10 & 18.87 & 5 & 9.43 & 9 & 16.98 & \\
\hline Installment & 5 & 9.43 & 10 & 18.87 & 6 & 11.32 & 1 & 1.89 & 0.100 \\
\hline The reason for choosing the marketin & hant & & & & & & & & \\
\hline Cash payment & 5 & 9.43 & 6 & 11.32 & 3 & 5.66 & 8 & 15.09 & \\
\hline Necessity & 2 & 3.77 & 8 & 15.09 & 3 & 5.66 & 0 & 0.00 & \\
\hline Higher price & 0 & 0.00 & 0 & 0.00 & 2 & 3.77 & 0 & 0.00 & $0006^{*}$ \\
\hline Familiarity & 5 & 9.43 & 5 & 9.43 & 3 & 5.66 & 0 & 0.00 & $0.006^{\circ}$ \\
\hline Proximity & 0 & 0.00 & 1 & 1.89 & 0 & 0.00 & 0 & 0.00 & \\
\hline Suitability to the quality of the product & 0 & 0.00 & 0 & 0.00 & 0 & 0.00 & 2 & 3.77 & \\
\hline The person who determines the sale $p$ & ef & ee prod & & & & & & & \\
\hline Buyer & 2 & 3.77 & 5 & 9.43 & 3 & 5.66 & 1 & 1.89 & \\
\hline Seller & 2 & 3.77 & 3 & 5.66 & 1 & 1.89 & 4 & 7.55 & \\
\hline Both of them & 8 & 15.09 & 9 & 16.98 & 4 & 7.55 & 3 & 5.66 & 0.324 \\
\hline Other & 0 & 0.00 & 3 & 5.66 & 3 & 5.66 & 2 & 3.77 & \\
\hline The place for learning market knowle & $e a b$ & it the pr & $d u c t$ & & & & & & \\
\hline By visiting the market directly & 6 & 11.32 & 11 & 20.75 & 4 & 7.55 & 6 & 11.32 & \\
\hline From other breeders & 4 & 7.55 & 6 & 11.32 & 3 & 5.66 & 2 & 3.77 & \\
\hline From friends & 1 & 1.89 & 1 & 1.89 & 3 & 5.66 & 1 & 1.89 & 0.558 \\
\hline From the Internet & 0 & 0.00 & 2 & 3.77 & 0 & 0.00 & 0 & 0.00 & \\
\hline Other & 1 & 1.89 & 0 & 0.00 & 1 & 1.89 & 1 & 1.89 & \\
\hline
\end{tabular}




\section{Discussion}

In our study, it was determined that $37.7 \%$ of the breeders sold their livestock to the brokers, $22.6 \%$ to the final consumers, $20.8 \%$ to the retailers, and $18.9 \%$ to more than one middleman. In a study conducted in the province of Niğde (Seçer and Boğa, 2016), it was stated that $89.7 \%$ of the breeders sold their livestock to retail butchers and $10.3 \%$ to merchants, sales were generally made in the farmyard, and the product prices were received in cash. In a study conducted in the province of Ardahan (Demir et al., 2015), it was reported that $86.4 \%$ of the enterprises did not use any middlemen when selling sheep or lamb, and $13.6 \%$ of them sold to merchants (drover). In their study, Tsourgiannis et al. (2005) determined that breeders sold their livestock to retail butchers by $21.7 \%$, to wholesalers by $56.7 \%$, to direct consumers by $5.4 \%$, to other farmers by $1 \%$, and reserved for their consumption by $6.1 \%$, and breeders used mixed channels (multi-channel) by $9 \%$. Some studies reported that breeders used more than one marketing channel. In the study conducted in the province of Muş (Kaymak, 2015), it was found that the breeders sold $59.6 \%$ of their livestock to merchants (drover), $27.4 \%$ to retail butchers, and $13 \%$ directly to consumers as sacrificial animals. In the study conducted in the province of Yozgat (Tamer, 2014), it was stated that the breeders sold their livestock mostly to the merchants (drover), at the rate of $36.5 \%$.

In the present study, it was determined that the variables of selling additional products other than livestock in sheep breeding enterprises, being a member of the Sheep and Goat Breeders Association, and the reason for the breeders to choose the marketing channels were effective in the marketing channel preference. Sales of additional products other than livestock in enterprises, in other words, selling milk, yogurt, and cheese along with livestock, provide an extra source of income for the breeders and ensures that there will be no cash shortage in case of a delay in payments. Breeders who do not have this opportunity increasingly tend to prefer channels with a cash payment (Thamthanakoon, 2019). Our study revealed that breed- ers who did not sell any product other than livestock mostly sold to brokers and retailers. Similarly, the case that breeders earned income from activities other than sheep breeding also enabled them to make more independent decisions when choosing channels. In a study conducted in Kenya, it was reported that breeders with additional off-farm income were more likely to sell through dairy cooperatives (Mburu et al., 2007). The advantage of having extra revenue increases the acceptability of late payments from the marketing channels.

Breeders' membership in a group (Sheep and Goat Breeders Association) is a significant variable that affects the decision making of channel selection. This group can be an association, cooperative, or another organization. Group membership and access to information (market, price, and production knowledge) significantly differ in different sectors and countries and affect channel selection in various ways. Generally, the group membership factor is associated with access to information (Girma and Abebaw, 2012; Thamthanakoon, 2019). Ahmed et al., 2016) found that access to market knowledge by small-scale Pakistani breeders had a positive effect on their market decisions, and Jari and Fraser (2012) determined that access to market information by breeders in South Africa had a positive impact on their market choices. Furthermore, breeders who are members of the Sheep and Goat Breeders Association benefit from government support. The opportunities provided by these supports to the breeders affect the choice of market channel. In their study, Girma and Abebaw (2012) reported that government subsidies increased the financial resources required for the breeder to operate more efficiently, and this situation considerably determined the breeder's decision regarding the market channel.

When the reasons for the breeders to choose the marketing channels were examined, it was determined that they made their decisions mostly due to cash payment and necessity. De Bruyn et al. (2001) reported that small businesses preferred cash payment because they needed ready money. Tsourgiannis et al. (2008) determined that the speed of payment had a significant effect from the viewpoint of sheep and goat breeders 
in Greece when selecting local milk processing plants, cooperatives, and large national dairy companies as their marketing channels. Hobbs (1997) found that fast payment was an important factor in selecting channels for cattle marketing. Similarly, in our study, it was determined that payment terms had a significant effect on the choice of marketing channel.

In Turkey, breeders are forced to sell their livestock because they have no competitive power and they need cash, and they hand over their animals to the first broker they meet (Dağdemir et al., 2003). Therefore, necessity was identified as another significant factor affecting channel choice.

The effect of the gender factor was found to vary in several studies. In some studies, gender was pointed out as a significant factor (Benedek et al., 2014; Girma and Abebaw, 2012). In some other studies, on the other hand, gender was not defined as a significant factor in marketing channel selection (Mutura et al., 2015; Srinivas et al., 2014; Kumar et al., 2011). Similarly, in our study, the gender factor was not found to be effective on channel selection.

Another factor that affects the breeder's choice of marketing channel is education. The effect of the level of education is realized by giving the breeder access to market information, and thus, they take more risks (Mutura et al., 2015; Kumar et al., 2011) found that more educated smallscale dairy farmers in Kenya were more likely to sell through cooperatives due to their ability to understand and interpret market information. In some other studies, on the other hand, the education factor was not found to be influential. The authors suggested that this fact could be explained by the slight differences between the educational levels of the breeders since the highest level of education among the respondents was secondary school (Soe et al., 2015). Similarly, in our study, the effect of education was not found to be significant.

The bargaining (negotiation) power of the breeder must be high in order to be the party that is influential on the sales price, in other words, the party that determines the price. In the previous studies, bargaining power is defined as an influencing factor in terms of decision making on channel selection. Bargaining power was found to have a significant impact on the marketing channel decisions of sheep and goat ranchers in the eastern Macedonia region of Greece (Tsourgiannis et al., 2008). In our study, the effect of bargaining power was not found to be significant.

Access to market information guides the decision of channel selection. It is important for breeders to obtain information about the market prices, the time of sale, and the point of sale so that they can choose the most appropriate channel for them(De Bruyn et al., 2001). In the study conducted in Ethiopia, it was reported that farmers' membership in agricultural cooperatives and the ability to easily access to market information reduce the likelihood of sales to local traders, increasing their direct access to consumers (Girma and Abebaw, 2012).

Market information can be accessed from different sources. Srinivas et al. (2014) identified government officials and other breeders as the main sources of market information. The sources most frequently used in our study were direct visits to the marketplace and the other breeders. However, the sources for gathering market information were not found to be effective on the marketing channel selection.

\section{Conclusion}

As a result of this research, the channels preferred by sheep breeders in sheep marketing, and the factors affecting their channel selections were explained. $37.7 \%$ of the breeders stated that they preferred to choose brokers in marketing their products, $22.6 \%$ final consumers, $20.8 \%$ retailers, and $18.9 \%$ more than one channel. It was determined that $71.7 \%$ of the breeders sold only livestock, and these people preferred brokers more. This situation causes the breeders to miss the opportunity of earning income by processing the products resulting from their production activity and their income to be limited. Besides, when assessing the breeders' marketing channel preferences according to their association memberships, their marketing channel decisions were more in favor of brokers in both breeder groups that were members and non-members of the association. Sheep breeders took into account 
the cash payment when choosing the marketing channel, or they sold their livestock to middlemen due to necessity. In the study, it was determined that the cooperative membership rate of the breeders was as low as $18.9 \%$. According to these results, it can be concluded that the majority of the breeders do not have a marketing organization, they need cash, and therefore they have limited opportunities to choose dealers and to compete. The case is that the breeders cannot get organized economically regarding marketing channels, or the existing cooperatives are quite inadequate. Through the active operation of the cooperatives and increasing the numbers of cooperative memberships, it will be possible to achieve efficiency in the marketing of livestock and other products and improve the profitability of the enterprises. In this context, it is important to implement policies that encourage producers to organize and also ensure the development of marketing and financing opportunities.

\section{References}

Ahmed U.I., Ying L., Bashir M.K., Abid M., Elahi E., Iqbal M.A., 2016. Access to output market by small farmers: The case of Punjab, Pakistan. Journal Animal Plant Science, 26(3): 787-793.

Aksoy A., Yavuz F., 2012. Analysis on the reasons for quitting sheep and goat rearing of farmers: a case of East Anatolia Region. Anadolu Journal Agricultural Sciences, 27(2): 76-79.

Albayrak M., Adanacıoğlu H., Taşdan K., Özden F., Çalış H., Ekmen M.E., Karaman E., Sağ E., Korkusuz S., Gençoğlu C., 2020. Agricultural Marketing Current Situation and Future. In: $9^{\text {th }}$ Agricultural Engineering Technology Congress of Turkey, Ankara, Vol. 2, pp. 749-787.

Aral Y., Çevrimli M.B., Akdoğan N., Aydın E., Arıkan M.S., Akın A.C., Ozen D., 2016. Investigation of intermediary margins in the marketing of beef and lamb meat in Ankara province, Turkey. Journal of the Faculty of Veterinary Medicine Kafkas University, 22(5): 685-691.

Benedek Z., Fertő I., Baráth L., Tóth J., 2014. Factors influencing the decision of smallscale farmers on marketing channel choice: a Hungarian case study. Paper presented at the European Association of Agricultural Economists 2014 Congress "Agri-Food and Rural Innovations for Healthier Societies", August 26-29, Ljubljana, Slovenia.
Bölük G., Karaman S., 2017. Market power and price asymmetry in farm-retail transmission in the Turkish meat market. New Medit, 16(4): 2-11.

Cevger Y., Aral Y., Sakarya E., 2011. Livestock Economy. Eskişehir Open Education Faculty Publication.

Dağdemir V., Birinci A., Atsan T., 2003. Marketing of red meat production and consumption in Turkey. Journal of the Faculty Agriculture University Atatürk, 34(4): 361-366.

Davies D.H., 2001. An investigation into the factors determining ruminant livestock distribution in the far South West. Unpublished PhD Thesis, University of Plymouth.

De Bruyn P., De Bruyn J.N., Vink N., Kirsten J.F., 2001. How transaction costs influence cattle marketing decisions in the northern cmmunal areas of Namibia. Agricultural Economics Research, 40(3): 405-425.

Demir P.A., Işık S.A., Aydın E., Yazıcı K., Ayvazoğlu C., 2015. Socio-economic importance of sheep breeding farms in Ardahan province. Van Veterinary Journal, 26(3): 141-146.

Escobar C., Gil J.M., 2016. Marketing channels for small wineries: a Means-End Chain approach. New Medit, 15(4): 33-41.

Fetoui M., Dhehibi B., Frija A., Sghaier A.N., Kassam S., Aw-Hassan A., Abdeladhim M.A., Sghaier M., 2020. Towards an innovative olive oil value chain: options for inclusive development in South-Eastern Tunisia. New Medit, 19(3): 3-20.

Girma M., Abebaw D., 2012. Patterns and determinants of livestock farmers' choice of marketing channels: micro-level evidence. Working Paper No 1, Ethiopian Economics Association, Ethiopian Economics Policy Research Institute (EEA/EEPRI).

Gong W., Parton K., Cox R.J., Zhou Z., 2007. Transaction costs and cattle farmers' choice of marketing channels in China. Management Research News, 30(1): 47-57.

Haines M., 1999. Marketing for Farm and Rural Enterprise. Ipswich: Farming Press.

Hobbs J.E., 1997. Measuring the importance of transaction costs in cattle marketing. American Journal of Agricultural Economics, 79: 1083-1095.

Jari B., Fraser G., 2012. Influence of institutional and technical factors on market choices of smallholder farmers in the Kat River Valley. In: Van Schalkwyk H.D., Fraser G.C.G., Obi A., van Tilburg A. (eds.), Unlocking markets for smallholders. Lessons from South Africa. Wageningen, the Netherlands: Wageningen Academic Publishers, Vol. 10, pp. 59-89. 
Kadanalı E.,Yazgan Ş., Dağdemir V., 2015. Sheep production and marketing in Ağr1 province. Scientific Bulletin-Economic Sciences, 14: 67-75.

Kaymak K., 2015. Socio-economic structure and production costs of sheep breeding enterprises in Korkut district of Muş province. Master Thesis, Erciyes University.

Kumar A., Staal S.J., Singh D.K., 2011. Smallholder dairy farmers' access to modern milk marketing chains in India. Agricultural Economics Research Review, 24(2): 243-253.

Mburu L., Wakhungu J.W., Gitu K.W., 2007. Determinants of smallholder dairy farmers' adoption of various milk marketing channels in Kenya highlands. Livestock Research for Rural Development, 19: 9-18.

McDonald J.H., 2014. Handbook of biolological statistics $3^{\text {rd }}$ ed. Baltimore, Maryland: Sparky House Publishing, pp. 29-115.

Ministry of Development, 2014. 10 $0^{\text {th }}$ Development Plan Onuncu (2014-2018). Ankara, Livestock Specialized Commission Reports. https://www.sbb. gov.tr/wp-content/uploads/2018/10/10_Hayvancilik.pdf. Accessed on January 2021.

Mutura J.K., Nyairo N., Mwangi M., Wambugu S.K., 2015. Analysis of determinants of market channel choice among smallholder dairy farmers in Lower Central Kenya. International Journal of Innovative Research and development, 4(10): 264-270.

Nyaupane N.P., Gillespie J.M., 2011. Factors influencing producers' marketing decisions in the Louisiana crawfish industry. Journal of Food Distribution Research, 42(2): 1-11.

Ozer O.O., 2011. An Analysis of Mutton with Asymmetric Price Transmission: The Case of Turkey. Turkish Journal of Agricultural Economics, 17(2): 55-63.

Seçer A., Boğa M., 2016. Marketing structure, problems and suggestions of small ruminant producti- on in Camardı district of Niğde province. Turkish Journal of Agriculture - Food Science and Techno$\log y, 4(2)$ : 79-83.

Soe W.P.P., Moritaka M., Fukuda S., 2015. An analysis of the factors influencing marketing channel choice by paddy rice farmers in Myanmar. JournalFaculty of Agriculture Kyushu University, 60(2): 535-542.

Srinivas T., Aw-Hassan A., Rischkowsky B., Tibbo M., Rizvi J., Naseri A.H., 2014. Factors affecting the goat producers' choice of market place and marketing efficiency in Afghanistan. Indian Journal Animal Sciences, 84(12): 1309-1314.

Tamer B., 2014. Socio-economic structure and production costs of sheep farms in central district of Yozgat province. Master Thesis, Erciyes University. Thamthanakoon N., 2019. Factors affecting marketing channel selection by rice farmers in Thailand. $\mathrm{PhD}$ Thesis, Harper Adams University.

Tsourgiannis L., Errington A., Eddison J., 2005. Marketing strategies of agricultural producers in objective one Greek regions: the factors affecting the selection of marketing channels of sheep and goat producers. In: Mattas K., Tsakiridou E. (eds.), Food quality products in the advent of the 21st century: production, demand and public policy. Chania: CIHEAM, pp. 307-320 (Cahiers Options Méditerranéennes, n. 64).

Tsourgiannis L., Eddison J., Warren M., 2008. Factors affecting the marketing channel choice of sheep and goat farmers in the region of East Macedonia in Greece regarding the distribution of their milk production. Small Ruminant Research, 79(1): 87-97.

TURKSTAT, 2019. Livestock statistics. Turkish Statistical Institute [online]. Available at http://www. tuik.gov.tr/Start.do. Accessed on June 2020. 